\title{
Innovation of Art Design Education in the New Era
}

\author{
https://doi.org/10.3991/ijet.v16i15.24889 \\ Xiaohui Zhang \\ Baoji University of Arts and Sciences, Baoji, China \\ yanbingbjwl@163. com
}

\begin{abstract}
Art design is a major driver of the development of culture and art, modern science and technology, and social economy. As a result, art design education has been greatly valued and attached great importance. However, art design education in China falls behind the development of social economy and art design. To solve the problem, this paper attempts to innovate art design education in China in the new era. Firstly, the authors investigated the current situation of art design education in China, and discovered a few problems: the chaotic teaching mode, the unreasonable curriculum setting, the mismatch between graduate capabilities and social requirements, and the undiversified teaching evaluation method. In response to these problems, art design education was renovated from the aspects of curriculum system setting, teaching mode, and teaching evaluation. On this basis, the authors proposed to set the curriculum system based on professional ability, and designed a topic-based and workplace-oriented teaching mode with art design studio as the platform. Finally, the innovation methods for teaching evaluation were discussed in terms of evaluation subject, evaluation standard, and evaluation method. The research findings provide a theoretical and practical reference for the innovation of art design education.
\end{abstract}

Keywords-art design education, curriculum system, teaching mode, teaching evaluation, innovation

\section{$1 \quad$ Introduction}

In human history, art design develops with the progress of human civilization. With the rapid development of social economy in China, the Chinese government has put forward the concept of "mass entrepreneurship and innovation", and as a result, the creative industry has become a new development trend of the information age, and art design education has been greatly valued by people and is receiving more attention.

The art design major is a profession with obvious creativeness and practicalness features, however, investigation results revealed that the development level of art design education in China is falling behind the development level of social economy and art design field. The traditional art design education is generally based on academic knowledge and experience, which is not conducive to developing students' innovative thinking, as a result, the students are cultivated to be 
armchair strategists and their capabilities are seriously out of touch with social practice, and they failed to meet the requirements of the society for high-quality talents in the new era [1]. In the context of global economic integration, the oldtype designers who only pay attention to skills and techniques can no longer satisfy the needs of industrial development, and the new designers in the new era should have personalized design ideas, keen observation skills, diversified cognition and understanding, good teamwork spirit, comprehensive practical ability, and the awareness of lifelong learning [2]. Therefore, the innovation of art design education in the new era is an objective demand for the rapid development of the world's creative industry (creative art industry). In China, the research on art design education started late, and there's a gap between domestic and foreign studies. In recent years, although domestic scholars have achieved fruitful results in terms of discipline positioning, curriculum setting, teaching mode, teaching method, and teaching quality evaluation of art design education [3], China's art design education has been deeply affected by the large-batch and fast-running Bauhaus schooling method, which has restricted the development of modern art design education in China [4].

Based on above concerns, this paper explores the current status and problems of art design education in China, by referring to advanced domestic and foreign teaching concepts and China's requirements for art design talents, it researched the innovation methods for the Chinese art design education in the new era from three aspects of curriculum setting, teaching mode, and teaching evaluation [5-8].

\section{Current status and existing problems of art design education in China}

\subsection{The chaotic teaching mode doesn't fit the requirements of the development of the times}

According to the different types of cultivated talents, the training targets of art schools are divided into a few types, the academic-type talents, the applied-type talents, and the technical-type talents, the differences of the three are listed in Table 1 [9]. According to the different subjects of talent cultivation, the art schools are divided into professional art schools, art majors in universities, and vocational art colleges [10]. The academic-type talents are the training objects of the master and doctor stages of professional art schools and art majors in universities, however, in terms of the cultivation of applied-type and technical-type talents, there isn't a clear job division among these different types of schools, their curriculum settings, teaching methods, and management means are basically the same, and most of them lay more emphasis on theoretical lecturing while paying less attention to the training of practice design skills; the proportion of theoretical courses is far greater than that of practical courses, resulting in that the hands-on ability and innovation ability of the graduates are very weak and cannot meet the requirements of the society for art design talents [11]. 
Table 1. Differences in the three types of cultivated art design talents

\begin{tabular}{|l|l|l|l|}
\hline \multicolumn{1}{|c|}{ Talent type } & Mastery of knowledge theory & \multicolumn{1}{|c|}{ Ability and quality } & Nature of the work \\
\hline $\begin{array}{l}\text { Academic-type } \\
\text { talents }\end{array}$ & $\begin{array}{l}\text { Complete system of theoretical } \\
\text { knowledge }\end{array}$ & $\begin{array}{l}\text { Discover objective laws and } \\
\text { study scientific principles }\end{array}$ & $\begin{array}{l}\text { Scientific research, } \\
\text { academic research }\end{array}$ \\
\hline $\begin{array}{l}\text { Applied-type } \\
\text { talents }\end{array}$ & Solid theoretical knowledge & $\begin{array}{l}\text { Practice ability, innovation } \\
\text { ability, comprehensive quality }\end{array}$ & $\begin{array}{l}\text { Planning and design, } \\
\text { management decision }\end{array}$ \\
\hline $\begin{array}{l}\text { Technical-type } \\
\text { talents }\end{array}$ & $\begin{array}{l}\text { Basic professional knowledge, } \\
\text { basic operating principles }\end{array}$ & $\begin{array}{l}\text { Proficient technical skills, } \\
\text { familiar with job business }\end{array}$ & $\begin{array}{l}\text { Production and } \\
\text { service line }\end{array}$ \\
\hline
\end{tabular}

\subsection{Unreasonable curriculum setting}

The art education in China grew out of the fine arts lessons, although the two have been separated during the gradual developing and maturing process, in terms of curriculum setting, most of the art schools still give more importance to painting basics and color basics in the fine arts lessons, and the curriculum setting is quite comprehensive [12]. Table 2 gives the curriculum setting of the environmental art design major in a university [13], according to the table, the curriculum covers a wide range, the courses are mainly basic knowledge introduction or overview, the design-type courses also cover a wide range; while there are few courses for environmental and ecological design and design material research that are necessary for environmental art majors, and there are few practical courses, as a result, the students' practical and hands-on abilities can hardly be trained.

Table 2. Curriculum setting of the environmental art design major in a university

\begin{tabular}{|c|c|c|}
\hline \multicolumn{2}{|c|}{ Course type } & Course Title \\
\hline \multicolumn{2}{|c|}{ General Education } & $\begin{array}{l}\text { Mao Zedong Thought and Chinese Aocialist Theories, An Overview of Basic } \\
\text { Principles of Marx, College English, College Writing, Introduction to Comput- } \\
\text { er Science, College Physical Education-Basic Course, College Physical Educa- } \\
\text { tion-Selective Course, Situation and Policy, Future Career and SYB Guidance }\end{array}$ \\
\hline Basic Course & $\begin{array}{l}\text { Compulsory } \\
\text { course }\end{array}$ & $\begin{array}{l}\text { Graphic Design, Design Aesthetics, Effect drawing, Foundation of Architec- } \\
\text { tural Design, Basics of Interior Design, Landscape Design, History of Chinese } \\
\text { Art and Design, Furniture design, Interior lighting design, Residential space } \\
\text { design, Office space design, the history of modern design in the world, Fur- } \\
\text { nishing art design, Commercial space design, Hotel space design, Decoration } \\
\text { materials and crafts }\end{array}$ \\
\hline \multirow{5}{*}{$\begin{array}{l}\text { Professional } \\
\text { Development } \\
\text { Course }\end{array}$} & $\begin{array}{l}\text { Language } \\
\text { skills } \\
\text { training }\end{array}$ & Language skills training 1-4 \\
\hline & $\begin{array}{l}\text { Academic } \\
\text { theory }\end{array}$ & $\begin{array}{l}\text { Chinese garden history, Chinese and foreign art history, Environmental psy- } \\
\text { chology, Ergonomics, Folk art, Design semiotics }\end{array}$ \\
\hline & $\begin{array}{l}\text { Application } \\
\text { Skill } 1\end{array}$ & Software foundation, public art design, Garden design, Model making \\
\hline & $\begin{array}{l}\text { Application } \\
\text { Skill } 2 \\
\end{array}$ & $\begin{array}{l}\text { Construction design, Brand Design, Interior design bidding plan, Barrier-free } \\
\text { product design }\end{array}$ \\
\hline & $\begin{array}{l}\text { Cross } \\
\text { coincidence }\end{array}$ & $\begin{array}{l}\text { Calligraphy foundation, Photography foundation, Layout design, Film and } \\
\text { television advertising, Chinese painting foundation }\end{array}$ \\
\hline \multicolumn{2}{|l|}{ Practice link } & $\begin{array}{l}\text { Landscape sketching, professional cognition inspection, graduation internship, } \\
\text { graduation design }\end{array}$ \\
\hline
\end{tabular}




\subsection{Graduates do not fit social requirements}

Now the many advertising companies and media companies have a large demand for designers, however, the shortage of excellent designers is a common phenomenon at present. According to statistics, a large number of art design majors graduate from art schools every year, but their employment status is not satisfactory [14]. This study selected four small and medium-sized advertising companies in Fuzhou City and used questionnaires to investigate the education background and work status of their employees.

Figure 1 shows the survey results of the work experience of employees in these companies, according to the figure, employees who have just graduated, or have one or two years of work experience accounted for large proportions, while employees with richer work experience (more than five years) accounted for a small proportion, only $13 \%$.

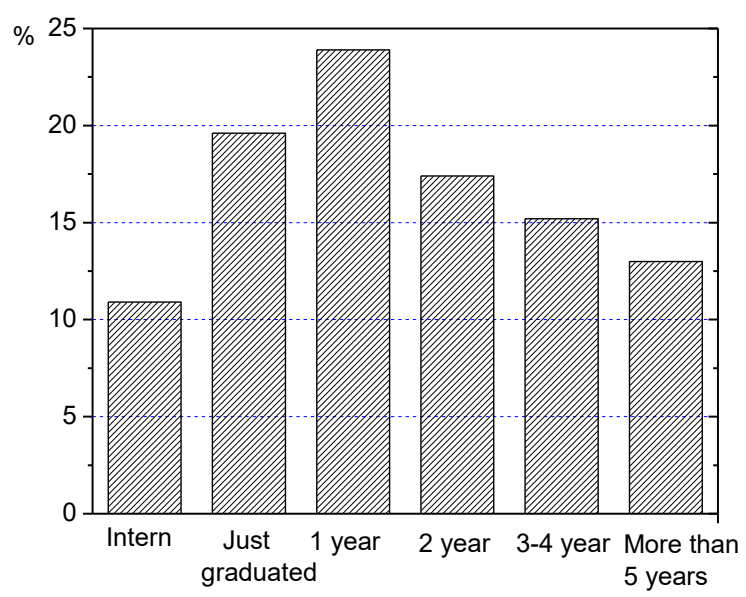

Fig. 1. Statistics of work experience of company employees

Figure 2 shows the survey results of independent work completion of employees in these companies, according to the figure, only about $10 \%$ of the employees can complete the design works independently and have the innovation and design ability required by the job positions, most employees (more than 40\%) are not able to complete the design works independently and they need assistance from others to modify their design works, moreover, about $20 \%$ of the employees have a certain sense of innovation, but since they lack of the practical experience or they cannot use the software skillfully, they are not qualified for the actual design works.

Table 3 shows the survey results of employers' evaluation on graduates or interns, according to the table, the employers' recognition of art design students is average, indicating that the cultivated art design majors do not meet the requirements of the society.

The survey also revealed that more than $85 \%$ of the employees have not received professional skill training, and the employer company leaders expressed that they hope the graduates could have creativity and could do the design works independently after they joined the company, the companies do not want to hire graduates that can 
only take up their posts after the companies spend money and power to train them, they are more willing to hire designers with rich experience.

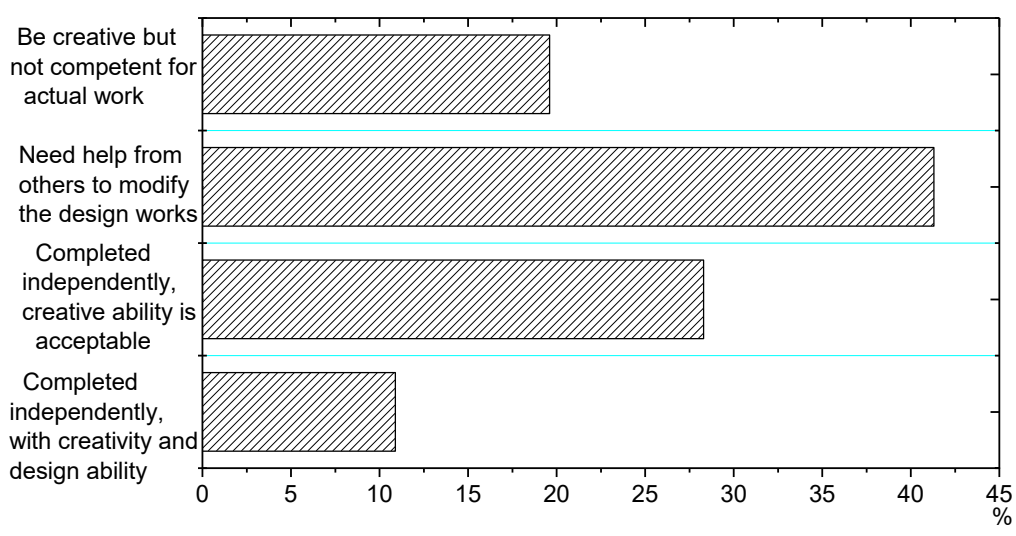

Fig. 2. Statistics of independent work completion of company employees

Table 3. Employer's evaluation on art design graduates or interns

\begin{tabular}{|l|l|l|l|l|}
\hline \multicolumn{1}{|c|}{ Evaluation item } & Excellent & Good & General & Poor \\
\hline Professional basic knowledge & $7 \%$ & $13 \%$ & $56 \%$ & $24 \%$ \\
\hline Work attitude & $11 \%$ & $26 \%$ & $54 \%$ & $9 \%$ \\
\hline Creativity & $4 \%$ & $12 \%$ & $61 \%$ & $23 \%$ \\
\hline Practical skills & $6 \%$ & $23 \%$ & $53 \%$ & $18 \%$ \\
\hline Team work & $18 \%$ & $32 \%$ & $38 \%$ & $12 \%$ \\
\hline Personal literacy & $15 \%$ & $53 \%$ & $30 \%$ & $2 \%$ \\
\hline
\end{tabular}

\subsection{Undiversified teaching evaluation mode}

The survey also discovered that the current teaching evaluation method of art design major is mainly the teacher evaluation, and the evaluation content mainly contains three parts: the usual performance (attendance, classroom performance, homework, etc.), final grades, and course design grades. The final grades take up about $50 \%$ of the total grades, and the evaluation standard is relatively single, the ranks of students in the class are usually determined by the evaluation standards set by the teachers [15].

\section{Innovation methods for art design education in the new era}

\subsection{Innovation of curriculum system setting based on professional ability}

Curriculum is the soul of teaching for art design education, and it emphasizes on scientificity and unity [16]. In order to cultivate applied-type innovative art design 
talents that meet the requirements of companies in the industry and fit the development level of regional and national economy, the setting of the curriculum system should start from the employee requirements of the employer companies and the ability requirements of art design work posts, then, it should form a professional curriculum setting instruction committee composed of discipline leaders, professional teachers, senior expert designers in the field, and employer companies, and join their efforts to analyze and demonstrate the setting of the curriculum system [17]. Due to the fast development and upgrade of the art design industry, after curriculum system has been implemented, it's necessary to regularly examine the implementation situation of the curriculum system, upgrade the technical development status of the art design field, and ensure the curriculum to be systematic, reasonable, advanced, and forwardlooking [18]. Figure 3 shows an overall framework of the art design curriculum system [19].

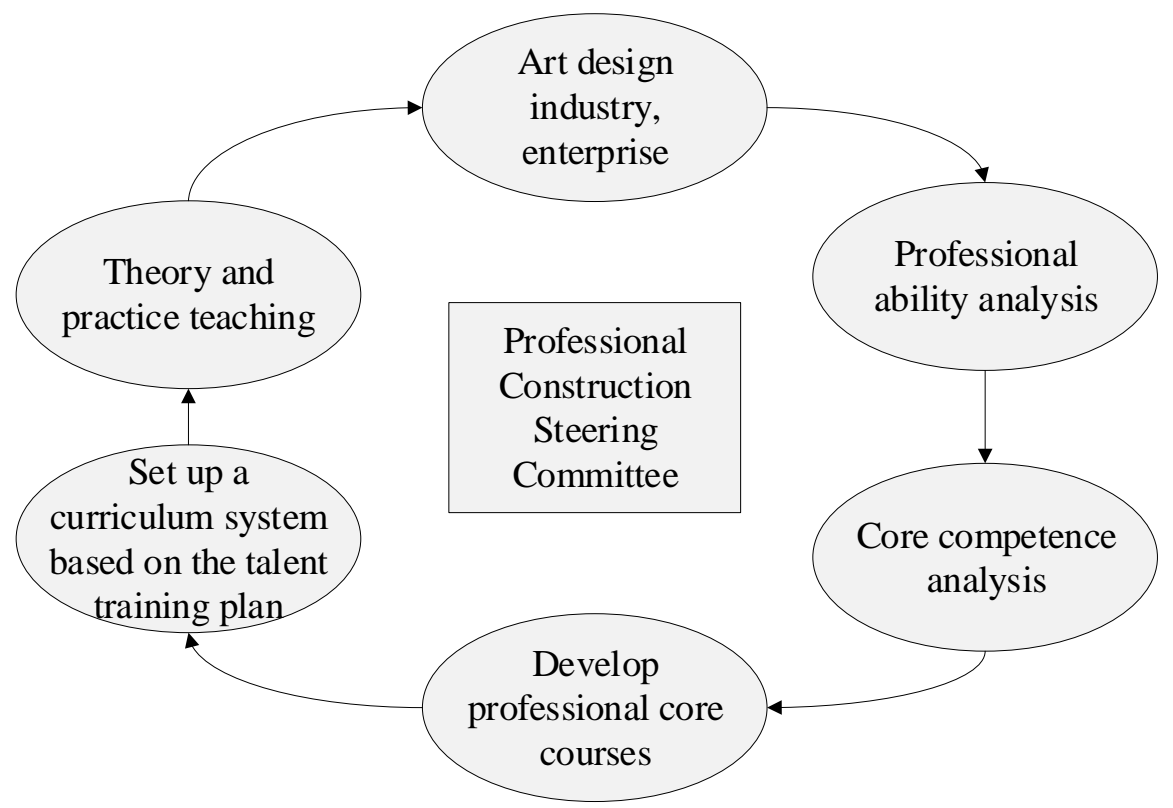

Fig. 3. Overall framework of art design curriculum system

\subsection{Innovation of teaching mode}

To alter the current situations such as the detachment between professional theories and practical teaching of art design major, and poor hands-on ability of students, and the inadaptation of students to the requirements of companies in the industry, it's necessary to innovate the teaching mode of the art design major, therefore, combining with relevant reference papers, this paper proposes the topic-based and workplaceoriented teaching mode with art design studio as the platform [20]". 


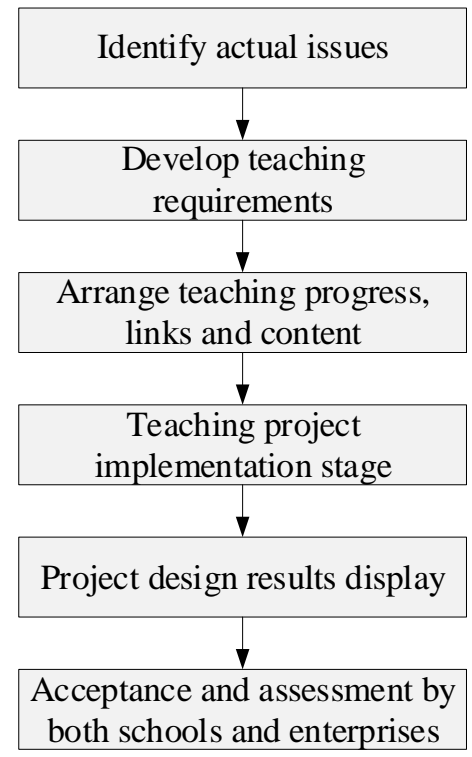

Fig. 4. Framework of topic-based and workplace-oriented teaching mode with art design studio as the platform

Art design studios are external social practice platforms established by the art design major. These studios should have designers with rich practical experience to participate in the teaching, and they should be able to introduce the actual design tasks and requirements into the teaching activities, and establish platforms that can connect teaching with practice, and connect students with the society [21]. Figure 4 shows the framework of the topic-based and workplace-oriented teaching mode with art design studio as the platform [22].

\section{(1) Identify actual teaching topics}

After art design studios receive real work orders from the society, they will choose actual work projects and identify actual teaching topics based on the art design talent training goals and the requirements of the professional abilities of students specified in the syllabus; according to the different courses learnt by different grades and the size of actual work projects, the teaching topics can be the entire project or the subprojects divided by teachers per the students' actual conditions [23].

\section{(2) Formulate teaching requirements}

When teachers formulate specific requirements for the teaching topics based on customer requirements and teaching goals, besides the common goals such as the knowledge goals, ability goals, and emotional and attitude goals, other goals such as publicity goals and display goals that the customers want to achieve should be included as well [24].

\section{(3) Arrange teaching progress, links, and content}

According to the connection between different teaching topics and courses, the teaching progress and specific teaching content of the courses should be reasonably arranged, the teaching links should be properly arranged based on students' mastery 
level of knowledge, and the lecturing method and proportions of theoretical and practical courses should be well arranged as well.

\section{(4) Implement the teaching topics}

The implementation phase of teaching topics is the key stage of art design education. The teaching implementation of the topic-based and workplace-oriented teaching mode with art design studio as the platform can be divided into four phases [25], as shown in Figure 5.

\section{1) Import phase}

Before implementing the teaching topics, the lecturing of theoretical knowledge is an indispensable part of the smooth implementation of teaching topics. After assigning the teaching topics to students, teachers should first teach students the basic design knowledge so that they could have a systematic understanding of the professional knowledge; then during the teaching of this phase, teachers should change the traditional lecturing mode, use the excellent design works and teaching cases to guide and inspire students' thinking and discussion; when discussing the pros and cons of the design works and applying the theoretical knowledge to the design practice, teachers need to teach students the methods and skills to understand, master, and use the knowledge, so that the students could have a clear understanding of the design ideas, which could lay a basis for the implementation of subsequent teaching topics [26].

\section{2) Design conception phase}

Teachers issue the specific requirements of the teaching topics to students, introduce to them the types of topics, explain the customers' ideas, needs, and uses, as well as the entry point of the topics. According to the information provided by teachers, students use the knowledge they learnt to search for relevant design materials via multiple ways such as surveys, internet, or libraries, they choose the entry point they believe is appropriate for the teaching topic to conceive the design and communicate with teachers or other students; then, teachers use their own practical experience to analyze students' design ideas according to the actual needs of customers, discuss with students to trigger the sparks of their thinking, inspire and instruct them to continue collecting materials, and determine their own design themes based on their creative ideas.

\section{3) Design finalization phase}

Based on the design ideas, determined themes, and collected materials of previous phases, students design the colors, structures, shapes, and other aspects and form the first design drafts. Then, according to the design drafts of students, teachers or the persons in charge of the teaching topics introduce the design schemes and design ideas, students discuss the design themes and propose modification suggestions, and make further modifications and improvements to the design drafts according to these suggestions and complete the design projects, forming the finalized design drafts. This phase can cultivate students' ability to discover, analyze, and solve problems, exercise their creative thinking, enable them to integrate theory with practice, learn while using, and find ways of expressing theoretical knowledge in art design. 


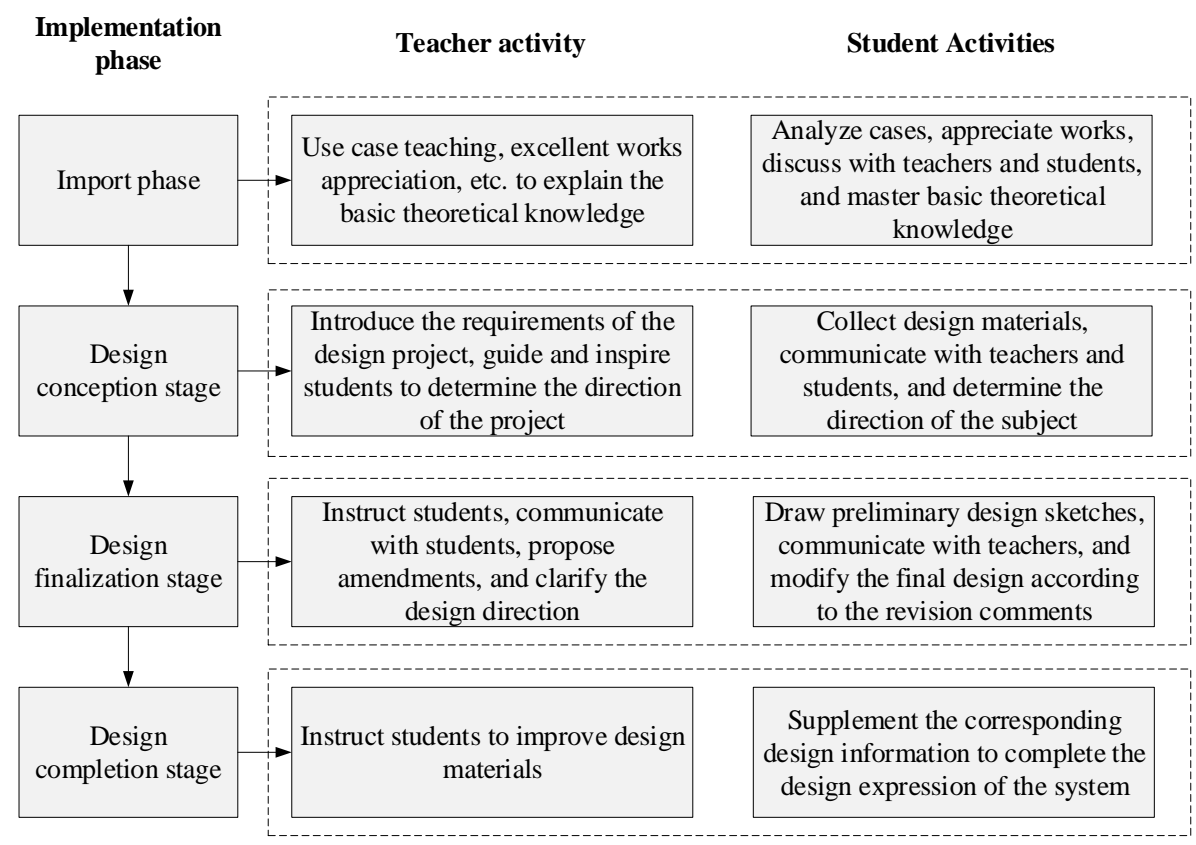

Fig. 5. Four phases of the implementation of the topic-based and workplace-oriented teaching mode

\section{4) Design completion phase}

Under the instruction of teachers, based on the finalized design drafts, students complete the materials related to the design themes, and form systematic expressions of the design themes, including contents such as the display of design drawings and the explanation of design ideas, this phase mainly cultivates students' comprehensive abilities such as typesetting design, and language expression, etc.

\section{(5) Display of teaching results}

After students complete the design, they hand over their finished design works to teachers and make PPT presentations, then in multimedia classrooms, teachers organize the relevant persons in charge of the teaching topics, if possible, relevant persons in charge of the client companies could be invited to participate in the presentations; students are required to wear suits to attend the presentation to simulate the real business environment, then they are asked to give presentations to introduce their design works, and use concise language to explain the concept, innovation, and connotation of their design works to teachers and client companies within the specified time. Teachers and the persons in charge of the client companies can ask questions or comment on the students' design works and encourage their innovations. After all the teaching results are demonstrated, client company leaders can choose the design works that can meet their needs as the final design schemes. During this process, students' innovative thinking and practical design skills could be improved, their design works could relate to the market demands, and they could feel the real business environment. This process is a key step for cultivating high-quality applied-type design talents. 


\subsection{Innovation of teaching evaluation}

Teaching evaluation is also an important link in the teaching process, which examines students' mastery of knowledge and skills. However, in traditional teaching evaluations, teachers are the main subjects of the evaluation, and the evaluations on students are mostly result-oriented, which is not conducive to cultivating students' creative thinking and ability. Therefore, it's necessary to innovate the teaching evaluation on students and realize diversified teaching evaluation. This paper proposes to innovate teaching evaluation from three aspects of evaluation subject, evaluation standard, and evaluation method, as shown in Figure 6.

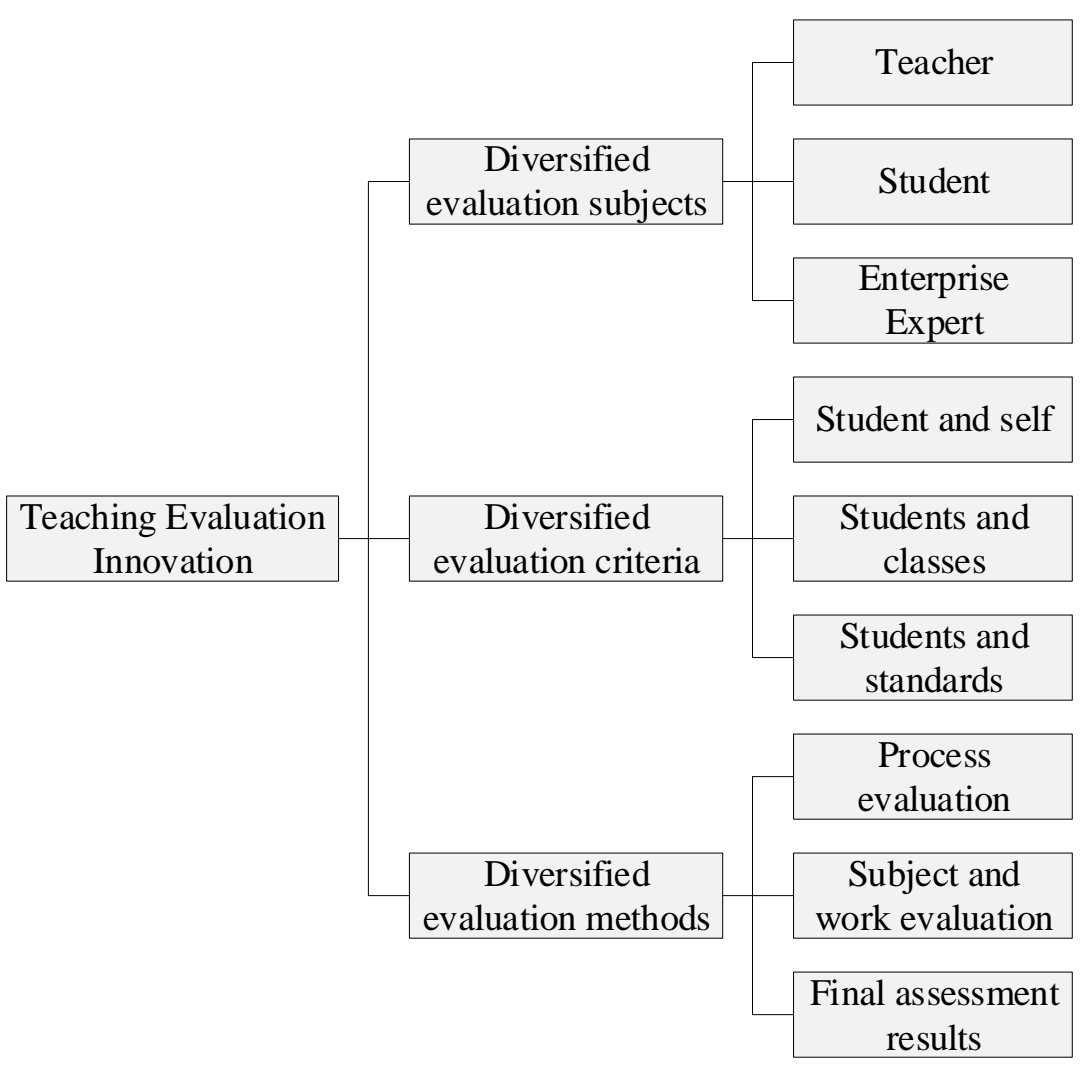

Fig. 6. Innovation of teaching evaluation

\section{(1) Diversification of evaluation subjects}

Based on the original teacher evaluation, student evaluation and company expert evaluation should also be introduced to make the evaluation subjects more diversified. The student evaluation includes two parts: student self-evaluation and student mutual evaluation. Company expert evaluation is the company's evaluation on the project schemes completed by the students, and the company experts' evaluations on the students enable them to better adapt to the requirements of the society for design talents. 


\section{(2) Diversification of evaluation standards}

The evaluation standards need to be expanded into diversified evaluation standards. Besides the original student evaluation based on expected course teaching goals and the horizontal evaluation based on students' ranks in the class, vertical evaluation could also be added to the evaluation standards, namely to vertically compare students' design ability level in the past and at present.

\section{(3) Diversification of evaluation methods}

The traditional evaluation methods are mainly based on the final exam scores or final course design results, these are result-based evaluation methods which have ignored the valuation on students' various abilities, if we want to cultivate students' design creative thinking and improve their comprehensive abilities, multiple evaluation methods must be adopted. Based on the original evaluation methods, other evaluation methods such as process-based evaluation method, topic evaluation, and homework evaluation could also be introduced. Process-based evaluation is to comprehensively evaluate the students' creative thinking ability, information literacy, teamwork spirit, communication skills, independent learning ability, and application capability during the entire learning and art design creation process. The project evaluation and homework evaluation are the evaluations on students' completion status of their daily design works and the teaching topics assigned by teachers.

\section{Conclusions}

The future art design education is facing the era of knowledge, economy, and technology. The goal of art design education is not to train designers, but to cultivate design talents with creativity, innovative thinking, and can adapt to the development of the times, thus the innovation of art design education is an inevitable trend. In the context of the new era, this paper studied the innovation methods for art design education, and drew the following conclusions:

(1) There are a few problems existing in the current art design education, including the chaotic teaching mode, the unreasonable curriculum setting, the mismatch of graduate capabilities and social requirements, and the undiversified teaching evaluation method.

(2) This paper proposed the concept of setting the curriculum system based on professional ability, and constructed an overall framework of art design curriculum system.

(3) This paper proposed a topic-based and workplace-oriented teaching mode with art design studio as the platform, built an overall framework of teaching mode, and gave detailed introduction and analysis on the specific implementation processes of the teaching mode.

(4) This paper explained the specific innovation methods for art design education from three aspects of evaluation subject, evaluation standard, and evaluation method. 


\section{$5 \quad$ References}

[1] Feng, W., Li, X. (2021). Innovative application research on the combination of art design and engineering practice education under the background of new media. International Journal of Electrical Engineering Education, 002072092110032. https://doi.org/10.1177/ 00207209211003267

[2] Weller, K., Lempp, H. (2010). The visualization and modification of the body in art and medicine - how an innovative special study module explored the humanity of medicine. Medical Education, 34(11): 951-951. https://doi.org/10.1046/j.1365-2923.2000.0784e.x

[3] Zhang, X., Ma, Y., Jiang, Z., Chandrasekaran, S., Wang, Y., Fonkoua Fofou, R. (2021). Application of Design-Based Learning and Outcome-Based Education in Basic Industrial Engineering Teaching: A New Teaching Method. Sustainability, 13(5): 2632. https://doi.org/10.3390/su13052632

[4] Wen, H.I., Zhang, S.J., Hapeshi, K., Wang, X.F. (2008). An innovative methodology of product design from nature. Journal of Bionic Engineering, 5(1): 75-84. https://doi.org/ $10.1016 / \mathrm{s} 1672-6529(08) 60009-8$

[5] Gao, Y. (2020). Blended teaching strategies for art design major courses in colleges. International Journal of Emerging Technologies in Learning, 15(24), 145-158. https://doi .org/10.3991/ijet.v15i24.19033

[6] Peng, J. (2020). Intelligent technology-based improvement of teaching ability of professional courses in art design. International Journal of Emerging Technologies in Learning, 15(23), 193-207. https://doi.org/10.3991/ijet.v15i23.19029

[7] Zhu, Y.B. (2020). Color management of digital media art images based on image processing. Ingénierie des Systèmes d'Information, 25(4), 445-452. https://doi.org/10. 18280/isi.250406

[8] Lyu, Y., Yang, X., Yao, J. (2020). Comprehensive evaluation and analysis of teaching and research performance of art majors. International Journal of Emerging Technologies in Learning, 15(20), 241-254. https://doi.org/10.3991/ijet.v15.i20.17425

[9] Emmanuel, E., Collins, D., Carey, M. (2010). My face, a window to communication: using creative design in learning. Nurse education today, 30(8): 720-725. https://doi.org/ 10.1016/j.nedt.2010.01.011

[10] Mateus-Berr, R., Al-Mousli, L., Carli, C.M.Y., Faißt, V., Gharashir, N., Girotto, L., Schober, M. (2020). Art and dementia education in times of COVID-19: Developing topics. Alzheimer's \& Dementia, 16: e047501. https://doi.org/10.1002/alz.047501

[11] Yeoman, P., Carvalho, L. (2019). Moving between material and conceptual structure: developing a card-based method to support design for learning. Design Studies, 64: 64-89. https://doi.org/10.1016/j.destud.2019.05.003

[12] Ott, M., Pozzi, F. (2011). Towards a new era for cultural heritage education: discussing the role of ict. Computers in Human Behavior, 27(4): 1365-1371. https://doi.org/10.1016/ j.chb.2010.07.031

[13] Steers, J. (2010). New realities for art and design education: an overview. International Journal of Art \& Design Education, 12(1): 9-24. https://doi.org/10.1111/j.14768070.1993.tb00570.x

[14] Edwards, R.A., Kirwin, J., Gonyeau, M., Matthews, S.J., Lancaster, J., DiVall, M. (2014). A reflective teaching challenge to motivate educational innovation. American Journal of Pharmaceutical Education, 78(5): 103. https://doi.org/10.5688/ajpe785103

[15] Hockey, J. (2003). Practice-based research degree students in art and design: identity and adaptation. International Journal of Art \& Design Education, 22(1): 82-91. https://doi.org/10.1111/1468-5949.00341 
[16] Bremner, M.N., Bennett, D.N., Chambers, D. (2014). Integrating Reiki and communityengaged scholarship: An interdisciplinary educational innovation. Journal of Nursing Education, 53(9): 541-543. https://doi.org/10.3928/01484834-20140820-02

[17] Yang, S., Zhao, Y.F. (2015). Additive manufacturing-enabled design theory and methodology: a critical review. The International Journal of Advanced Manufacturing Technology, 80(1): 327-342. https://doi.org/10.1007/s00170-015-6994-5

[18] Hockey, J. (2003). Practice-based research degree students in art and design: identity and adaptation. International Journal of Art \& Design Education, 22(1): 82-91. https://doi.org/10.1111/1468-5949.00341

[19] Rogers, M., Plaster, J. (2010). Art education in initial teacher education: a negotiated education. International Journal of Art \& Design Education, 13(2): 173-187. https://doi.org/10.1111/j.1476-8070.1994.tb00712.x

[20] Kelley, T.A. (2001). The art of innovation: Lessons in creativity from IDEO, America's leading design firm (Vol. 10). Broadway Business.

[21] Jiang, T., Yang, J. (2020). Teaching of practice innovation of new media interactive for art design training in college. International Journal of Electrical Engineering Education, 002072092094444. https://doi.org/10.1177/0020720920944443

[22] Carpenter, B.S., Taylor, P.G. (2006). Making meaningful connections: interactive computer hypertext in art education. Computers in the Schools, 23: 149-161. https://doi.org/10.1300/j025v23n01_13

[23] Jiang, L.J., Song, B., Su, J., Li, Z.L., Bont, C.D. (2016). The application of cloud innovation in industrial design education. MATEC Web of Conferences, 52: 03003. https://doi.org/10.1051/matecconf/20165203003

[24] Byrne, D., Kelliher, A., Cox, D., Rikakis, T. (2013). XSEAD: A community platform for art-science integration. IEEE Multimedia, 20(4): 4-7. https://doi.org/10.1109/mmul. 2013.63

[25] Mejlhede, D.T. (2015). Design research and art-based design education programs. Design Issues, 31(4): 44-55. https://doi.org/10.1162/desi_a_00350

[26] Walker, E.B., Boyer, D.M., Benson, L.C. (2019). Using Studio Culture to Foster Epistemic Change in an Engineering Senior Design Course. IEEE Transactions on Education, 62(3): 209-215. https://doi.org/10.1109/te.2019.2898151

\section{Author}

Xiaohui Zhang, (1976), female, obtained her master degree from Northwest University. She works in Baoji University of Arts and Sciences as a lecturer. Her main research direction are visual communication design and bronze art. Email: yanbingbjwl@163.com

Article submitted 2021-06-18. Resubmitted 2021-07-25. Final acceptance 2021-07-26. Final version published as submitted by the authors. 